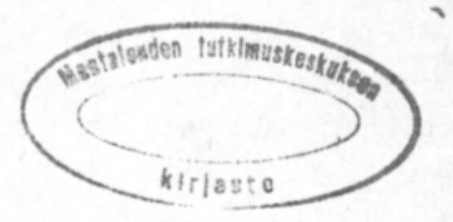

\title{
Ensiling, preservation losses and effluent binding of sugar beet tops
}

\author{
Maija-Liisa Salo \\ Department of Animal Husbandry, University of Helsinki, 00710 Helsinki
}

\begin{abstract}
Sugar beet tops harvested with a mower chopper make a good silage, without additives, but the losses through effluent are great. A low silo model - flat silo or stack - reduces the losses.

Effluent losses can also be decreased by ensiling dry straw with tops. Straw binds the effluent $3-5,5 \mathrm{~kg} / \mathrm{kg}$, corresponding to $150-200 \mathrm{~g}$ dry matter $/ \mathrm{kg}$, of which about $60 \mathrm{~g}$ is crude protein. About $20-25 \mathrm{~kg}$ long straw/tn beet tops is suitable in the feeding of cattle.
\end{abstract}

\section{Introduction}

When the sugar beet grows in the Finnish climate, the weight of tops amounts to the same as for the crops beet, i.e. about $25-30 \mathrm{tn} / \mathrm{ha}$. Since the tops are nowadays harvested by mower chopper the yield is about a quarter less.

Harvesting by mower chopper reduces the soil contamination of the tops thus increasing their energy value. The protein content is higher and that of sugar lower when the necks of roots are not taken with the tops. These tops have about the same feed value as pasture grass. In Finland about one half of the top yield is fed to livestock, the other half being ploughed in. The high mineral and protein content make the beet tops a good fertilizer, however, their profitability would increase if they were fed to cattle.

\section{Materials and methods}

The ensiling of sugar beet tops was studied on the Viik Experimental Farm in the years 1971-1974 (Salo and Sormunen 1974, Salo 1975). The tops were ensiled in a large tower-silo $\left(180 \mathrm{~m}^{3}\right)$ or in small silos $\left(11-16 \mathrm{~m}^{3}\right)$ or in stacks. 
Experiments were made using jute sacks. The weighed amouts of tops and/or binding material were put into the sacks which were then placed in different places in the silos or stacks. The contents of the sacks were weighed again when they came out during the feeding period.

The samples of the beet tops and corresponding silages were dried for analyses in a vacuum at $40^{\circ} \mathrm{C}$. Analyses were made by standard methods or by SALO's methods $(1965,1969)$. In vitro digestibility was measured according to TILley and TERRY (1963). F.u. values were calculated on the basis of in vitro digestibility and composition (SALo 1975). Digestible crude protein values were calculated according to HøJLAND FREDERIKSEN (1969).

\section{Results and discussion}

The composition of fresh and ensiled beet tops

The keeping quality of fresh tops is not good, but they can be ensiled, without presevatives, to a valuable silage (Table 1).

Table 1. The composition of sugar beet tops harvested by mover chopper and corresponding silage, averages of years $1971-1973$.

\begin{tabular}{|c|c|c|}
\hline & Fresh tops & Tops silage \\
\hline $\begin{array}{l}\text { Dry matter, } \% \\
\% \text { of dry matter }\end{array}$ & 13,1 & 18,2 \\
\hline Crude protein $. . . \cdots \cdots \ldots \ldots . . .$. & 19,3 & 19,5 \\
\hline Sugars ........................ & 18,9 & 2,6 \\
\hline Water-sol. org. acids ...... & 6,0 & 13,6 \\
\hline Crude fibre $. . . \ldots \ldots \ldots \ldots \ldots . . . . . .$. & 10,6 & 14,6 \\
\hline 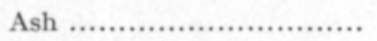 & 19,4 & 17,9 \\
\hline Hemicellulose (1971) ........ & 15,8 & 20,0 \\
\hline Cellulose $\quad$ (1971) ....... & 8,3 & 11,8 \\
\hline Crude lignin $\quad$ (1971) ....... & 3,0 & 3,8 \\
\hline In vitro digestib. of OM, $\%$ & 82,1 & 78,2 \\
\hline Kg DM/f.u. .................. & 1,25 & 1,3 \\
\hline DCP g/f.u. ................. & 190 & 185 \\
\hline Pepsin soluble CP, g/f.u. & 205 & $\left.205^{1}\right)$ \\
\hline
\end{tabular}

1) $\mathrm{NH}_{3}-\mathrm{N}$ subtracted

As ensilage raw material tops have their positive and negative points. The positive one is the high nutritive value of the dry matter. The in vitro digesttibility is about $82 \%$ which means that their energy value for ruminants is about 0,8 f.u. per $\mathrm{kg}$ dry matter (f.u. $=0,7$ strarch units) . The crude protein content is high and the composition of amino acids is good, e.g. the lysine content about 5,5 g/16 $\mathrm{g} \mathrm{N}$ (SALO and LAAKso 1977). As a source of minerals the beet tops are extraordinary (Table 2). The high sugar content is advantageous in the ensiling. 
Table 2. The mineral composition of sugar beet tops and corresponding silage. Averages of years $1971-1973$.

\begin{tabular}{|c|c|c|c|c|}
\hline & & & Fresh tops & Tops silage \\
\hline \multicolumn{3}{|c|}{ 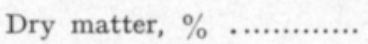 } & 13,1 & 18,2 \\
\hline \multicolumn{3}{|c|}{ Ash, $\%$ of DM $\ldots \ldots \ldots \ldots$} & 19,4 & 17,9 \\
\hline \multicolumn{3}{|c|}{$\mathrm{Ca}$ g/kg DM $\quad \ldots \ldots \ldots \ldots \ldots$} & 13,8 & 17,4 \\
\hline $\mathrm{P}$ & , & .............. & 2,4 & 2,1 \\
\hline $\mathrm{Mg}$ & , & (n............ & 7,3 & 7,3 \\
\hline $\mathrm{Na}$ & , & (n............ & 12,3 & 9,1 \\
\hline $\mathrm{K}$ & , & (n............ & 47,7 & 40,8 \\
\hline $\mathrm{Cl}$ & , & (n............ & 33,4 & 21,3 \\
\hline \multicolumn{2}{|c|}{ Fe mg/kg DM } & (n............ & 650 & 840 \\
\hline $\mathrm{Cu}$ & , & (n............ & 16 & 18 \\
\hline Mn & , & (n............ & 355 & 410 \\
\hline $\mathrm{Zn}$ & - & ….......... & 420 & 480 \\
\hline
\end{tabular}

In turn, a negative point is the high moisture content which causes large effluent and fermentation losses during preservation. On the other hand, no packing of the silos is needed as harvested tops form a wet pulp. The high mineral content means a high osmotic pressure, but because the composition of minerals is very basic (Table 3), the high level is only detrimental for ensilage.

Table 3. The principal acidic and basic substances of sugar beet tops and top silage.

\begin{tabular}{|c|c|c|}
\hline & \multicolumn{2}{|c|}{ g ekv./kg DM } \\
\hline & Fresh tops & Top silage \\
\hline \multicolumn{3}{|l|}{ Acidic substances } \\
\hline 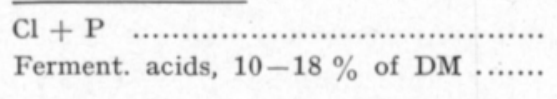 & 1,1 & $\begin{array}{l}0,7 \\
1,2-2,2\end{array}$ \\
\hline Basic substances & & \\
\hline $\begin{array}{l}\overline{\left.\mathrm{K}+\mathrm{Na}+\mathrm{Mg}^{1}\right)} \ldots \ldots \ldots \ldots \ldots \ldots \ldots \ldots . . . \\
\mathrm{NH}_{3}-\mathrm{N}, 5-25 \% \text { of total } \mathrm{N}\end{array}$ & 2,4 & $\begin{array}{l}2,1 \\
0,1-0,6\end{array}$ \\
\hline
\end{tabular}

1) $\mathrm{Ca}$ omitted as unsoluble.

\section{Preservation losses}

Beet tops have been ensiled as follows: The tops are harvested with a mower chopper and the load dumped into the silo or onto the ground for stacking. The tops are covered with a plastic sheet and protected from the cold with straw bales and, in the case of stacks, further so with soil. A furrow is ploughed around the stack for effluent and rainwater.

Since the tops are very wet material they must be ensiled in a low layer, in a flat silo or stack. Even in a silo of $5 \mathrm{~m}$ high and of volume of $180 \mathrm{~m}^{3}$ the weight of the fodder has a markedly detrimental effect on the nutritive value and the losses of the silage in the lower part as compared with the upper part of it (Table 4). 
Table 4. The composition of silages and losses in upper and lower parts of concrete silo $\left(180 \mathrm{~m}^{3}\right)$.

\begin{tabular}{|c|c|c|}
\hline & \multicolumn{2}{|c|}{ Depth } \\
\hline & $1-2 \mathrm{~m}$ & $3-4 \mathrm{~m}$ \\
\hline Number of sacks ..................... & 4 & 4 \\
\hline Dry matter, $\%$......................... & 16,9 & 21,1 \\
\hline Composition, \% of DM & & \\
\hline Crude protein...$\ldots \ldots \ldots \ldots \ldots \ldots$ & 21,7 & 17,8 \\
\hline Sugars ............................. & 6,3 & 1,3 \\
\hline Org. acids ........................ & 17,0 & 10,4 \\
\hline Crude fibre $. . . \ldots \ldots \ldots \ldots \ldots \ldots \ldots . . . . . .$. & 12,4 & 17,2 \\
\hline 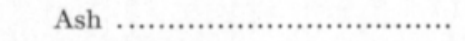 & 18,4 & 16,9 \\
\hline In vitro digestib., $\% \quad \ldots \ldots \ldots \ldots . . .$. & 80,4 & 77,0 \\
\hline 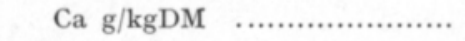 & 13,8 & 17,3 \\
\hline $\mathrm{P} \quad, \quad \ldots \ldots \ldots \ldots \ldots \ldots \ldots \ldots \ldots \ldots$ & 2,3 & 1,9 \\
\hline 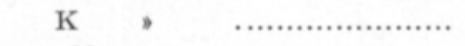 & 45,7 & 29,7 \\
\hline 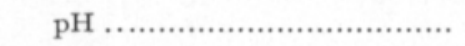 & 4,0 & 4,0 \\
\hline $\mathrm{NH}_{3}-\mathrm{N}, \%$ of total $\mathrm{N}$............... & 4,1 & 4,1 \\
\hline Losses, $\%$ & & \\
\hline 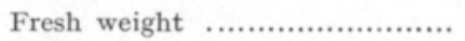 & 35 & 65 \\
\hline 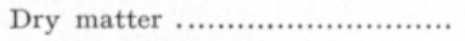 & 23 & 36 \\
\hline In vitro digestible $\mathrm{OM} \ldots \ldots \ldots \ldots$ & 26 & 40 \\
\hline 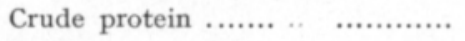 & 17 & 30 \\
\hline 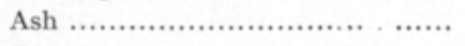 & 29 & 49 \\
\hline 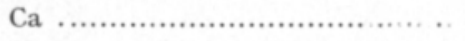 & 26 & 30 \\
\hline 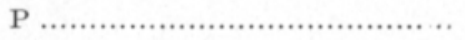 & 20 & 43 \\
\hline 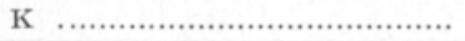 & 18 & 58 \\
\hline
\end{tabular}

The moisture content of beet tops varies between $85-90 \%$ (according to the amount of rain over the harvest period), differences in this value having a noticeable effect on the losses (Table 5).

Small variations in the dry matter composition also occur between years. If the autumn is ve1 y cold, the sugar content is low. For the ensilage the cold weather is advantageous, because the fermentation level remains small, the sugar level being high enough for sufficient fermentation even in a cold autumn. The silos and stacks of 1973 (Table 5) are a representation of the tops of a cold autumn, the stacks being made of quite snowy tops. The snow somewhat increased the amount of effluent, but the quality, composition and palatability of the silage was excellent.

The ensiling of tops into a stack demands a smooth area which slopes gently downwards. A furrow must be ploughed around the stack for the effluent and to prevent rainwater from flowing into the stack. The successful stack made in year 1973 was done according to these rules.

In 1974 , on the contrary, the stack was made on a meadow and the ploughing of the furrow was omitted. The tops were harvested in the rain and, after a wet summer followed a mild wet winter. The effluent and rainwater could not flow away freely from the hollows under the stack, with the result that good quality feed was found only in the upper part of the stack. The nearer to the bottom, the wetter and more spoiled the silage was. The acid content was 
Table 5. Composition and losses of silages in small silos or stacks.

\begin{tabular}{|c|c|c|c|c|}
\hline & \multicolumn{2}{|c|}{ Silos $11-16 \mathrm{~m}^{3}$} & \multicolumn{2}{|c|}{ Stacks } \\
\hline & 1972 & 1973 & Good 1973 & Bad 1974 \\
\hline \multicolumn{5}{|l|}{ Fresh tops } \\
\hline Dry matter, $\%$.............................. & 11,9 & 14,1 & 14,5 & 10,8 \\
\hline 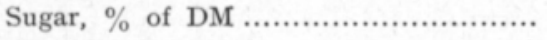 & 22,1 & 12,5 & 16,9 & 19,3 \\
\hline Crude protein,$\ldots . . . . . . . . . . . . . . . . . . . . . . .$. & 17,9 & 20,1 & 21,1 & 18,8 \\
\hline \multicolumn{5}{|l|}{ Silage } \\
\hline Org. acids, $\%$ of DM ....................... & 14,1 & 15,4 & 10,4 & 17,8 \\
\hline Crude protein $\quad, \quad$........................ & 18,3 & 20,0 & 21,0 & 20,5 \\
\hline pH & 3,8 & 4,2 & 4,6 & 4,8 \\
\hline 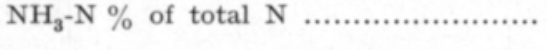 & 5,8 & 5,6 & 4,1 & 12,8 \\
\hline \multicolumn{5}{|l|}{ Losses, \% } \\
\hline 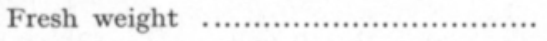 & 51 & 39 & 42 & 58 \\
\hline 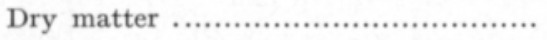 & 31 & 21 & 23 & 45 \\
\hline 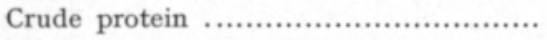 & 31 & 24 & 25 & 40 \\
\hline In vitro digestible $\mathrm{OM}, \ldots \ldots \ldots \ldots \ldots \ldots \ldots$ & 34 & 22 & 26 & 50 \\
\hline 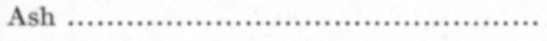 & 37 & 24 & 30 & 45 \\
\hline 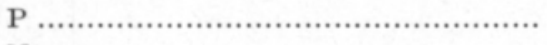 & 34 & 37 & 39 & - \\
\hline 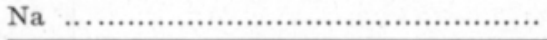 & 51 & 32 & 37 & - \\
\hline
\end{tabular}

high, but even so the $\mathrm{pH}$ was up to $6-7$. The high content of basic minerals means a great neutralizing capacity when the effluent cannot flow out freely (Table 3). The ammonium content further increases the basicity (in this case the ammonium nitrogen being up to $25 \%$ of total nitrogen). On the whole, the stack of 1974 was a good indication of what will follow if the necessary main rules are not followed.

\section{Losses in effluent}

The loss of fresh weight is $40-50 \%$ depending on the initial moisture content of the tops. It can be still higher if the tops are very wet. Great amounts of minerals flow out in the effluent as shown from the averages in Table 6. Of course the effluent also contains a lot of organic matter (sugars, fermentation acids, nitrogenous substances), but a simple calculation of them is not reliable, because a large portion of them decompose. On the whole the effluent is an extraordinary nutrient for microbes, or in other words, the worst form of environmental pollution.

Table 6. The effluent and mineral losses in small silos $\left(11-16 \mathrm{~m}^{3}\right)$ and stacks. Averages of normal years $(1972-1973)$.

\begin{tabular}{|c|c|c|c|}
\hline \multicolumn{2}{|c|}{ Effluent ....... } & $320-410$ & $\mathrm{~kg} / \mathrm{tn}$ tops $=$ loss of water \\
\hline $\mathbf{K}$ & .............. & $2,2-2,9$ & $=$ total loss \\
\hline $\mathrm{Cl}$ & ............... & $1,6-2,0$ & , \\
\hline $\mathrm{N}$ & (n............. & $1,0-1,2$ & , \\
\hline $\mathrm{Na}$ & .............. & $0,5-0,7$ & , \\
\hline $\mathrm{Mg}$ & (............... & $0,13-0,20$ & , \\
\hline $\mathrm{P}$ & ............... & $0,10-0,15$ & , \\
\hline $\mathrm{Ca}$ & (............... & 0,06 & - \\
\hline
\end{tabular}




\section{Binding of effluent}

Jute sacks were also used in order to study the possibility of diminishing the effluent losses. As binding materils were long straw, an autumn aftermath (32\% dry matter), newspaper and oat or barley grains. The binding matter was put into sacks either alone or with the tops.

The main results were as follows: Dry material, straw and newspaper bound effluent at a rate of about $3-\mathbf{5 , 5} \mathrm{kg}$ per $\mathrm{kg}$, corresponding to $150-200 \mathrm{~g}$ effluent dry matter. The main components were crude protein and organic acids (Table 7). $\mathrm{K}, \mathrm{Cl}$ and $\mathrm{Na}$ were the three most plentiful minerals.

Table 7. Increase of crude protein content of the material ensiled with tops.

\begin{tabular}{|c|c|c|c|}
\hline & & $\%$-units of & natter \\
\hline & & variation & $\overline{\mathbf{x}}$ \\
\hline & 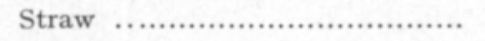 & $4-10$ & 6 \\
\hline & Newspaper .......................... & $3-7$ & 4 \\
\hline & Aftermath $(32 \%$ DM) $\ldots \ldots \ldots \ldots \ldots$ & $5-8$ & 6 \\
\hline & Oat and barley grains ............... & $0-1$ & 0 \\
\hline & Increases in the in vitro digestibil & lity were: & \\
\hline ? & 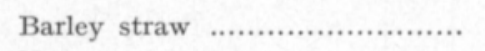 & $40 \%$ & $6 \%$ \\
\hline & Newspaper ............................ & $16 \%$ & \\
\hline
\end{tabular}

The straw was the best binding material. Its crude protein content increased by about 6 percentage units. The aftermath bound well, taking into account its high moisture content, suggesting that the fine roughage material might be better than a rough long straw. The newspaper was not as good as the straw. Its nutritive value is also poorer as a result of the high lignin content (over $20 \%$ ) and the printer's ink. The composition of the oat and barley grain dry matters changed very little in the silo. They got wet but scarcely bound any effluent dry matter. No loss in their starch or protein content occurred either.

The effect of straw on the preservation losses was studied by putting long barley straw and tops into sacks with $20 \mathrm{~kg}$ straw/tn tops and comparing the result with sacks which contained only tops. The straw reduced the dry matter losses, on average, by $22 \%$ and the crude protein losses by $35 \%$ (Table 8 ). The tops of this experiment were very wet, the dry matter content being only $11 \%$.

Table 8. The decrease of losses when barley straw $(20 \mathrm{~kg} / \mathrm{tn}$ tops) was ensiled with tops.

Decrease of losses, \%

$\begin{array}{ll}\text { Fresh weight } \ldots \ldots \ldots \ldots \ldots \ldots \ldots \ldots & 18 \\ \text { Dry matter } \ldots \ldots \ldots \ldots \ldots \ldots \ldots \ldots \ldots & 22 \\ \text { Organic matter } \ldots \ldots \ldots \ldots \ldots \ldots \ldots & 19 \\ \text { Ash } \ldots \ldots \ldots \ldots \ldots \ldots \ldots \ldots \ldots \ldots \ldots \ldots \ldots & 26 \\ \text { Crude protein } \ldots \ldots \ldots \ldots \ldots \ldots \ldots \ldots & 35\end{array}$




\section{Practical application}

If one wishes to bind the effluent in practice the best material seems to be straw or some other dry fodder, e.g. over a year old hay. If the straw is used in a long form, its quantity must be adjusted according to the voluntary intake of it by cattle and not with the purpose of binding the whole amount of effluent.

The ensiling of straw with tops will be thought of, in particular, by farmers who have planned to give up haymaking. The roughage requirement of cattle can in this case be supplied with long straw ensiled with tops. According to a scanty experiment with heifers, the proportions are about $20 \mathrm{~kg}$ straw/tn beet tops, for milk cows perhaps $25 \mathrm{~kg} / \mathrm{tn}$ tops.

The following calculation shows what kind of feed will result with a level of $25 \mathrm{~kg}$ straw/tn tops:

As the basis of calculation average facts are taken: the dry matter content of the fresh beet tops is $13 \%$, that of the straw $85 \%$ and the dry matter loss of tops during the preservation period $20 \%$.

In the tops-straw silage (dry matter $20 \%$ ) the proportion of straw in the dry matter is about $17 \%$. The mixture contains about $17 \%$ crude protein and $19 \%$ crude fibre of the dry matter, and has an vitro digestibility of organic matter about $71 \%$.

The calculation shows that according to its composition the mixture is equal to grass silage. If the cow will consume $30-40 \mathrm{~kg}$ per day of it, she will receive $1,2-1,6 \mathrm{~kg}$ long straw. This calculation suggest that the proportion of straw may be greater, but in practice, a part of straw is often left over because the long straw is easy to separate from the tops. In the experiments of NørGaARD Pedersen (1978) cows willingly ate much higher straw concentrations in beet tops-straw silage, but the straw was ground into a meal or cut to small pieces, which the animals were not able to separate from beet tops.

According to the results with jute sacks $20 \mathrm{~kg}$ of straw/tn tops is capable of binding about one fifth of the effluent when the moisture content is normal $(86-88 \%)$, and a flat silo or stack are used. At least $80-120 \mathrm{~kg}$ straw $/ \mathrm{tn}$ is needed for the total amount of effluent. Up to a half of this quantity can be mixed with beet tops without impairing the preservation result, but when one takes into account the voluntary intake by cattle only one quarter of it, at the most, can be used.

\section{REFERENCES}

Højland Frederiksen, J. 1969. Beregning of fodervaerdien i graesmarksafgroder, roer og roetop. 371. Ber. Fors. lab. 46 p. Kobenhavn.

Nørgaard Pedersen, E. J. 1978. Ensilering af bederoetop iblandet halm. N. J. F. -seminar Middelfart 29.-3.1978 4 p.

SALO, M.-L. 1965. Determination of carbohydrate fractions in animal foods and faeces. Acta Agr. Fenn. 105: 1-102.

- -1975 . Sokerijuurikkaan naatit rehuna. 1. Karjatalous 1975, 9: 26-28, 2. Karjatalous 1975, 10: 35-36.

,$- \&$ Kotrlainen, K. 1969. Determination of free and combined plant acids. J. Scient. Agric. Soc. Finl. 41: 277-289. 
- _ \& LaAkso, E. 1977. The digestibility and nutritive value of sugar beet top silage for sows. J. Scient. Agric. Soc. Finl. 49: 203-208.

- - \& Sormunen, R. 1974. Sokerijuurikkaan naatit ja niistä valmistettu säilörehu. 1. J. Scient. Agric. Soc. Finl. 46: 88-96., 2. J. Scient. Agric. Soc. Finl. 46: 97-102.

Trlley, J. M. A. \& TerRy, R. A. 1963. A two-stage technique for the in vitro digestion of forage crops. J. Brit. Grassl. Soc. 18: 104-111.

Ms received May 15, 1978

\title{
SELOSTUS
}

\section{Sokerijuurikkaan naattien säilönnästä, säilöntätappioista ja puristemehun sidonnasta}

\author{
Maija-Liisa Salo \\ Helsingin yliopiston kotieläintieteen laitos, 00710 Helsinki 71
}

Kelasilppurilla korjatut sokerijuurikkaan naatit ovat laidunruohon veroista rehua. Niistä saadaan myös hyvää säilörehua ja lisäksi ilman säilöntäainetta, sillä naattien runsas sokeripitoisuus ja syksyn viileä sää estävät virhekäymistä. Säilöntätappiot näin märällä raaka-aineella ovat kuitenkin suuret. Matala säilömalli - laakasiilo tai auma - vähentää puristemehutappioita.

Puristemehutappioita voidaan vähentää myős säilömällä naattien mukana kuivaa olkea. Kilo olkea sitoo $3-5.5 \mathrm{~kg}$ puristemehua eli $150-200 \mathrm{~g}$ kuiva-ainetta, mistä määrästä noin $60 \mathrm{~g}$ on raakaproteiinia. Nautakarjan ruokinnan kannalta sopiva seossuhde on $20-25 \mathrm{~kg}$ pitkää olkea/tn naatteja. 